\title{
AUTOMATION OF THE CONTROL PROCESSES OF THE REFRIGERATION UNITS CONDENSERS
}

\author{
V. BUKAROS ${ }^{1^{*}}$, O. ONISHCHENKO ${ }^{1}$, G. NALEVA ${ }^{2}$, A. BUKAROS ${ }^{3}$ \\ ${ }^{1}$ Department of Fleet Operation and Maintenance, National University "Odessa Maritime Academy", Odessa, UKRAINE \\ ${ }^{2}$ Department of Higher Mathematics, National University "Odessa Maritime Academy", Odessa, UKRAINE \\ ${ }^{3}$ Department of Electromechanics and Mechatronics, Odessa National Academy of Food Technologies, Odessa, UKRAINE \\ *email: eralife84@gmail.com
}

\begin{abstract}
In the article energy efficient ways of the condensing pressure (temperature) control in refrigeration units for various purposes are considered. The comparative analysis of the circuit solutions of the condensing temperature regulators for air cooling condensers is conducted with simulation methods. Modeling of the single-phase system of the regulator pulse-phase control triac HPC1/4 showed that this system has a low power factor. The feasibility of the condensing temperature regulators implementation on the basis of the three-phase frequency converter with DC chain is substantiated for the low and medium cooling capacity refrigeration units. The disadvantages of the existing systems of the condensing pressure stabilization of the refrigeration units water cooling condensers are highlighted. The research of two proposed control systems of the water-cooled condensers of the medium and high cooling capacity refrigeration units is conducted. It is established that the using of the principles of partial invariance to main disturbances with elements of the nonlinear correction can improve the energy efficiency of refrigeration units. Also it is provided by modeling the processes in the shell and tube capacitor KTP-300 of the ship refrigeration unit that the using of variable structure systems further improves the dynamic quality of control processes with large fluctuations of the heat loads.

Keywords: refrigeration unit; condenser; condensing pressure; condensing temperature regulator; control system.
\end{abstract}

\section{АВТОМАТИЗАЦІЯ ПРОЦЕСІВ КЕРУВАННЯ КОНДЕНСАТОРАМИ ХОЛОДИЛЬНИХ УСТАНОВОК}

\section{В. М. БУКАРОС ${ }^{*}$, О. А. ОНИЩЕНКО, Г. В. НАЛЕВА ${ }^{2}$, А. Ю. БУКАРОС}

\author{
${ }^{1}$ Кафедра технічної експлуатачії флоту, Начіональний університет «Одеська морська академія», Одеса, УКРАЇНА \\ ${ }^{2}$ Кафедра вищої математики, Національний університет «Одеська морська академія», Одеса, УКРӒ̈НА \\ ${ }^{3}$ Кафедра електромеханіки та мехатроніки, Одеська начіональна академія харчових технологій, Одеса, УКРАЇНА
}

\begin{abstract}
АНОТАЦІЯ Методами імітаиійного моделювання проведений порівняльний аналіз схемотехнічних рімень регуляторів температури конденсації. Обтрунтовано доцільність реалізації таких регуляторів на базі трифазного перетворювача частоти з ланкою постійного струму. Проведено дослідження двох систем керування охолодженням водяних конденсаторів холодильних установок. Доведено, щзо використання запропонованих алгоритмів управління дозволить підвищчти енергетичну ефективність холодильних установок і якість динамічних процесів управління при значних коливаннях теплових навантажень.
\end{abstract}

Ключові слова: холодильна установка; конденсатор; тиск конденсації; регулятор температури конденсації; система керування.

\section{Introduction}

Refrigeration units of different purpose (industrial, transport, household, medical, air conditioners, freezers chests and cooling showcases) are appreciable energy consumers. Any of such units is equipped with a condenser (e.g., air cooled condenser, ventilator cooling tower, cooling water supply pump, etc.). A fact is wellknown [1] that the condensing pressure (temperature) of the refrigerant significant impacts on the summary electricity consumption of the refrigeration unit.

For example, condensation temperature increasing nothing more than $1{ }^{\circ} \mathrm{C}$ leads to the increase in compressor consumed power of the refrigeration unit not less than $2 \ldots 2,5 \%$. It should be noted some features of ship refrigeration unit's operation.

Firstly, the compressor and heat-exchange equipment are required to provide the functioning of the refrigeration unit with a maximum thermal load and surrounding temperature.

Secondly, possibility of working must be provided at low temperatures (when the condensation temperature decreases).

Thirdly, certain ratio must be maintained between the condensing pressure and discharge pressure for providing of the minimum total energy consumption of the refrigeration unit for any thermal loads. Thus, it becomes clear how important to stabilize at the required level with specific features and conditions of unit operation.

The condensing pressure regulators are always built in the modern refrigeration units refrigerant coolant loop. The main function performed by such regulator is the stabilizing of the refrigerant given condensing pressure Pc during some changes, e.g., the temperature 
and condensing water flow for water shell-and-tube condensers and the air accordingly for air condensers.

Different condensing pressure stabilization systems are used in marine, industrial and household refrigeration units with the air or water cooling condensers.

The raise of the refrigeration unit energy parameters could be accomplished by the reducing of the condensing pressure to the lowest possible level. This explains the relevance of the proposed research.

\section{The aim of the paper}

Purpose and task of the research are developing of the energy efficiency methods of condensing pressure control in different assignment refrigeration units equipped by condensers with forced water cooling or air fan cooling.

Purpose is achieved by using of the executive mechanisms electric drives automatic control bases, fractional invariance bases to main disturbances with nonlinear correction elements and changed structure in stabilization systems.

\section{The object and the subject of the paper}

The object of research is processes of automatic pressure (temperature) control of refrigeration units.

The research subject is control systems and pressure (temperature) stabilization in refrigeration units with different types and refrigeration capacity.

\section{Control systems of air cooling condenser (refrigeration units with small and little capacity)}

For the last two or three years a lot of refrigeration equipment famous producers (Alco Controls - FSX-42S, Aspen - BN27.3WA and others) offer for the sale or equipped their conditioners and refrigeration units with condensing temperature regulators (CTRs). For example, typical representatives of such regulator are models HPC $1 / 4$ and LAC-1/7, produced by the company EDC International Ltd (Great Britain), FASEC-33, -100, -500 by firm ELIWELL (France). They have external thermo sensor, fixed to the air condenser jacket of the or conditioner, one or two programmed discrete outputs and possibility of the smooth control of the stabilized set value.

All companies propose connect own regulators to asynchronous three-phrase motors of the air condenser fans, moreover electrical motor turns into one-phrase network in condenser mode.

After the analysis of various producers different circuits common building principle of the named condensing temperature regulators was found. It is onephrase voltage control system with an optotriac in the power circuit. The one regulator consumer price $(220 \mathrm{~V}, 4$ A) in Ukraine fluctuates in cost from 100 till 135 USD. The continual rate increase of electric power allows affirming that capital costs for condensing temperature regulation system with such device will be compensated during period from 6 months till 2 years depending on the changes of the thermal loads and exploitation conditions, also refrigeration unit production. Questions of the dynamic processes quality, power consumption processes, condenser fan production regulating range for CTRs are still open. Obviously, that all CTR tasks could be decided not only experimentally, but by simulation methods quicker and more effective.

It is clear that it is extremely important to identify possibilities of the CTRs of the refrigeration units in the connection of the fan electric motor and offer alternative solutions.

It is assumed that the air condenser fan of the refrigerator unit is equipped with asynchronous threephrase motor type 4AA63B4 with technical data: $0.37 \mathrm{~kW}, \quad 3 \times 220 \mathrm{~V}, \quad 1.2 \mathrm{~A}, \quad \cos \varphi_{n}=0,69, \quad \eta_{n}=68 \%$, $\omega_{n}=142,8 \mathrm{rad} / \mathrm{s}$. Engine integral inertia $J_{\Sigma}$ with fan, which joined to its shaft is $16,25 \cdot 10^{-4} \mathrm{~kg} \cdot \mathrm{m}^{2}$.

Recommended by producers [2] output voltage tunings of the regulator $\mathrm{HPC} 1 / 4$ are following: the minimum voltage $\left(V_{\min }\right)$ is $70 \mathrm{~V}$ and the fan should switch off; adjusting operating voltage $\left(V_{\text {work }}\right)$ is $145 \mathrm{~V}$ and provides the condensing optimal temperature of the refrigeration unit. Once device is switched on motor is supplied with full voltage for $10 \mathrm{~s}$. This time is necessary for completing the fan's motor start process and heating by condenser refrigerant vapors with temperature sensor fixedly connected to it. After $10 \mathrm{~s}$ the regulator enters to the stabilization mode that must occur when the voltage on the motor is around $145 \mathrm{~V}$ for the nominal condensing temperature.

A simulation model of a single-phase system of triac CTR pulse-phase control are developed in the environment of Matlab for the research of the described modes. The control system synchronizes with the network, the reference voltage is sawtooth. The substitutional circuit parameters of the induction motor is calculated by the method [3].

Starting and working condensers of the engine, when connecting of the phases by "triangle" $\left(C_{\text {work }}=20.0 \mu \mathrm{F}, C_{\text {start }}=30.0 \mu \mathrm{F}\right)$, defined by the formulas [5] given by the fact that the phase current should not exceed nominal $(1.2 \mathrm{~A})$ value at maximum speed and maximum static load. The static characteristic of the fan is described by the known dependence of the torque $M$ from speed $\omega: T=T_{i}+k \cdot \omega^{2}$, where the idling torque $T_{i}=0.06 \mathrm{Nm}$, and the coefficient of viscous friction $k=1,21 \cdot 10^{-4} \mathrm{Nm} \cdot \mathrm{s}^{2} / \mathrm{rad}^{2}$.

The transient processes of the condenser fan induction motor start are shows in Fig. 1.

At time $t=0.15 \mathrm{~s}$ starting capacity $C_{\text {start }}$ is disconnected and only operating capacitor remains connected to the engine.

Graphs of voltage and current consumed by the three-phase condenser motor from single-phase network in this mode are shown in Fig. 2. 


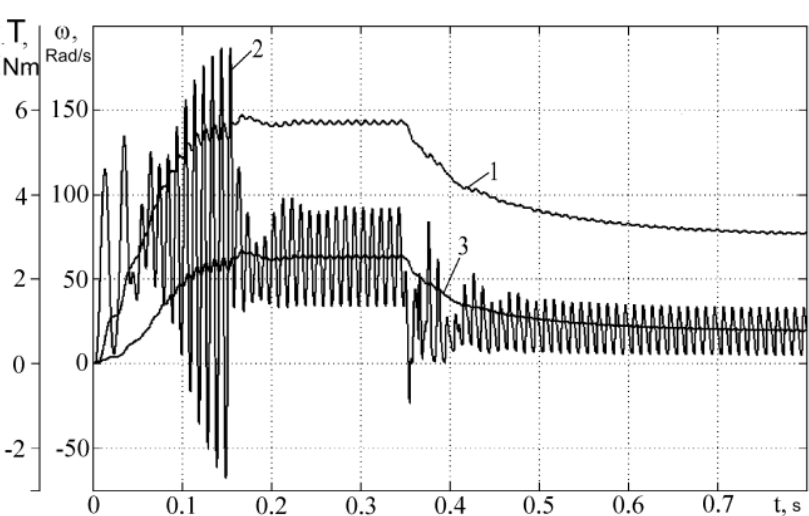

Fig. 1 - Process of the start and exit at a lower speed in the system of CTR with voltage regulator: 1 -fan speed, 2 -torque, 3 - static torque
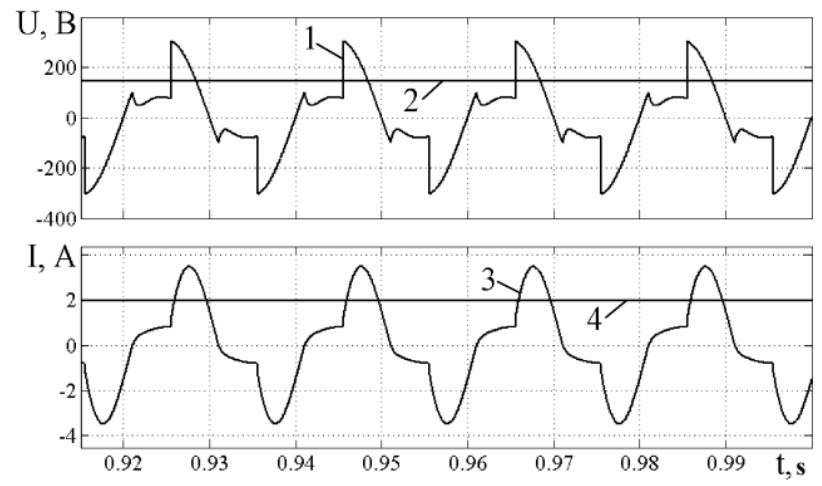

Fig. 2 - The reduced speed area:

1 and 2 -instantaneous and effective voltage values on the engine; 3 and 4 -instantaneous and effective consumption network current values

The obvious conclusion about a very low power factor [4] of the system with a voltage regulator should be from the analysis of the motor consumption current shape, that almost impossible to improve by simple means in the circuit.

In addition, a significant torque pulsations (Fig. 1) in the steady state with the likely heating coils, the inability to work with a nominal load installed for threephase motor, speed pulsations causing increased fan noise allow to doubt not only the price of the offered products but also the feasibility of proposed solutions using for motors by more than 15 to $20 \mathrm{~W}$.

It is obvious that due to the relatively high prices the use of industrial frequency converters usually with redundant functional service capabilities and that need a speed control range of not more than $2 . . .3$ with engine power up to $500 \mathrm{~W}$ for CTR is inappropriate.

A lot of possible technical solutions are revealed for making of the controllable electric drives of the CTR systems for example based on [5]. One of the simplest variants of the CTR concept realization is the three-phase frequency converter with a DC circuit [6] and singlephase bridge controlled or half-controlled rectifier.
It is assumed that the frequency of the converter is constant $(50 \mathrm{~Hz})$, and the control signals act only on the rectifier bridge for the purpose of physical implementation as simple as possible and therefore inexpensive and reliable three-phase system CTR.

For the same, as described above, CTR system functioning conditions will be compared using simulation with the voltage regulation system with capacitor motor and electric drive, which is based on the frequency converter and controlled rectifier.

Some system simulation results with the frequency converter are shown in Fig. 3.

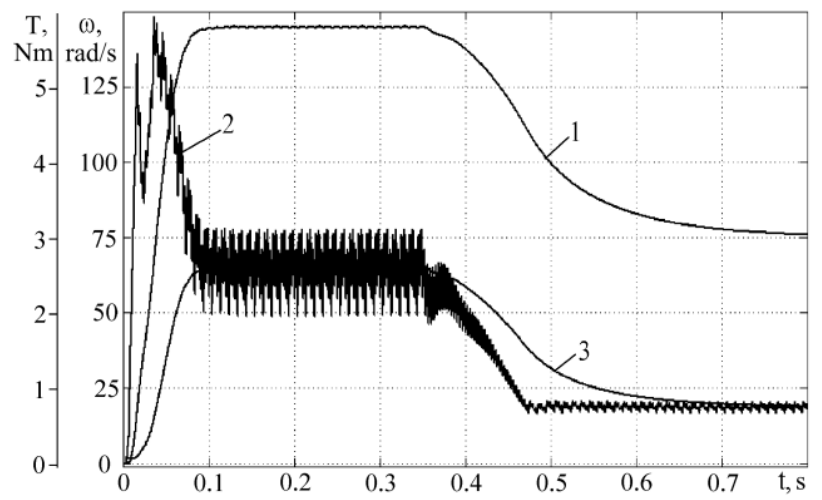

Fig. 3 - Process of the start and exit at a lower speed in the system of CTR with frequency converter: 1 -fan speed, 2 -torque, 3 - static torque

At time $t=0.35 \mathrm{~s}$. is being formed a control angle of the rectifier bridge and steady-state speed is provided circa $75 \mathrm{rad} / \mathrm{s}$.

Voltage graphs on the phase and phase consumption current at steady low speed are shown in Fig. 4. The network current shape is similar to the given one [7].
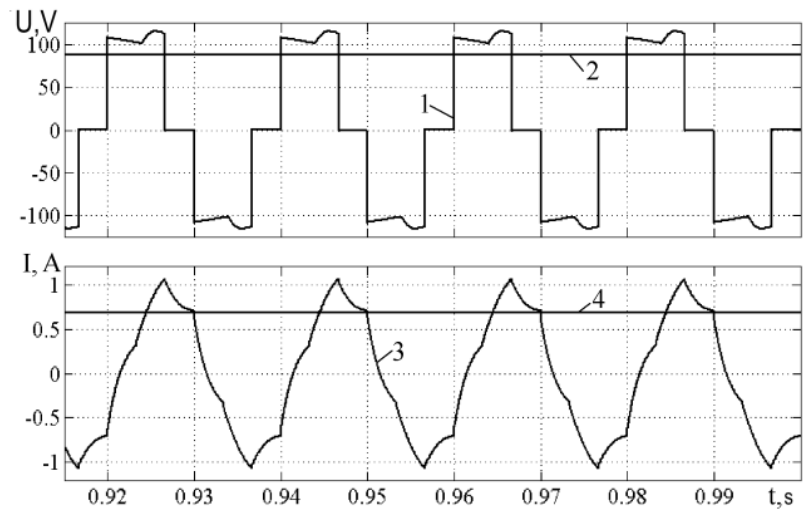

Fig. 4 - The reduced speed area by the system of CTR with frequency converter working:

1 and 2 -instantaneous and effective voltage values on the engine; 3 and 4 -instantaneous and effective phase current values 
If it considers the additional possibility of the installation the power factor active correction device [8] after the controlled rectifier that the price of the considered system CTR could not exceed 60 USD of the equivalent terms, in the serial production in Ukraine, while CTR network current will be almost sinusoidal.

\section{Control systems of water cooling condenser} (refrigeration units with medium and high capacity)

There are different types of the pressure regulators of the water cooling condenser. The most popular types are controlled pumps of cooling water, or controlled by the individual actuator of the turning valves.

All known stabilization systems have one general lack. It is the support (stabilization) of a predetermined and fixed condensing pressure, regardless of the fact that the air or water cooling temperature can significantly decrease in real conditions.

Typical functional and structural scheme of the condensing pressure control circuit is shown in Fig. 5,a,b.
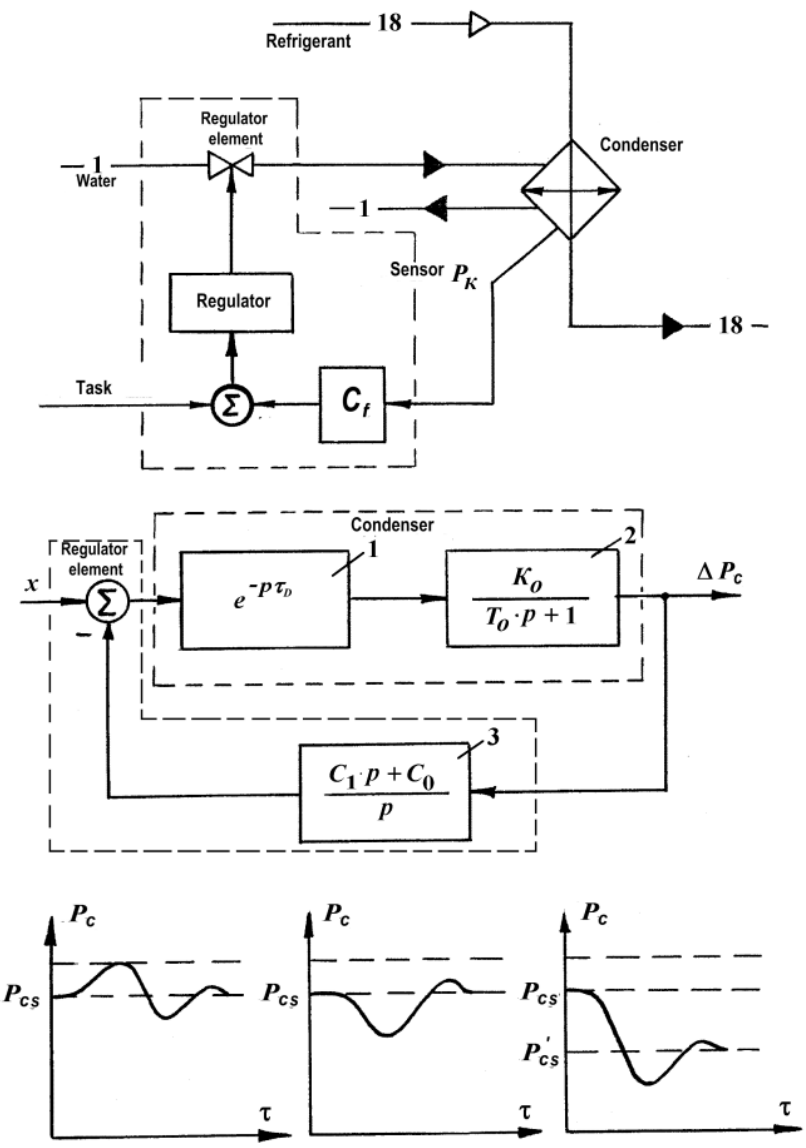

Fig. 5 - Functional (a) and structure (b) scheme of the condensing pressure control system and processes of the condensing pressure regulation $(c, d, e)$

However, according to the control method by scheme that shown in Fig. 5, there is a significant lack, which consists in the following. It is known that the reducing of the condensing pressure $P_{c}$ of the refrigerant corresponds to a decrease of the power consumption by the refrigeration unit compressor. According to various literature sources [9-10], reduction of the condensing temperature (or condensing pressure) refrigerant on $1{ }^{\circ} \mathrm{C}$ leads to the reduction of costs of electric power from $1.5 \%$ to $4 \%$ while cooling capacity $Q_{0}$ is increasing. These positive properties are explained by the reduction of the load on the compressor that delivers the refrigerant overheated pair in the condenser. Obviously, the reduction of the condensing pressure value can be caused by an increase of the flow of cooling water and (or) decrease of its temperature. Condensing pressure increases that leads to the reduction of the flow and (or) increase of the water temperature in the control system that shown in Fig. 5. The regulator opens the actuator to a larger angle; thereby it increases of the cooling water flow. The previous increased condensing pressure value $P_{c}$ decreases and stabilized on the level of the set pressure $P_{c s}$ in the plot (Fig. 5, c).

A dynamic process will proceed similar to described one, when it is flow increase and (or) temperature reduction of the cooling water (Fig. 1, d).

In last case, the condensing pressure could be reduced due to the existence of excess energy of water to the level $P^{\prime}{ }_{c s}$, but the regulator stabilizes the pressure $P_{c}$ at a fixed pre-specified level $P_{к 3}$ and eliminates the positive effect of external disturbances from an energy point of view.

Thus, there are unused possibilities of more energy-efficient ways to regulate the condensing pressure in the ship's refrigeration systems, which are equipped with water cooling condensers.

The first way allows at the expense of the additional feedback insertion of cooling water flow $G$ and the temperature $t$ to reduce the condensing pressure according to the changes of the disturbance namely increasing flow and (or) reduction the temperature of the water. Structural scheme of such system of the condensing pressure regulation with additional feedback connections is shown in Fig. 6.

The system consists of a cold water circuit (regulation object), regulator and negative feedback sensor on the pressure with feedback transfer coefficient $K_{f}$. As can be seen from the figure, two feedback connections are additionally included into this system through the regulator set input (except set signals $U_{s}$ and the main pressure (temperature) feedback connection $U_{f P}$ ). The first feedback connection is used for water flow with a flow sensor $W F$. The second feedback connection is used for water temperature with the temperature sensor $W T$. The sensor signals balance at the zero level of the output voltage in the refrigeration unit operation nominal mode using the elements of comparison 2 and 3 and balancing voltages, $U_{b G}$ and $U_{b t}$. That is, the output signals are following $U_{1}=0$ and $U_{2}=0$ in the refrigeration unit operation nominal mode. The output signals of the comparison elements $U_{1}$ and $U_{2}$ act in nonlinear blocks NB1 and NB2, which pick up sensor feedback connections signals of $U_{f G}$ and $U_{f t}$. 


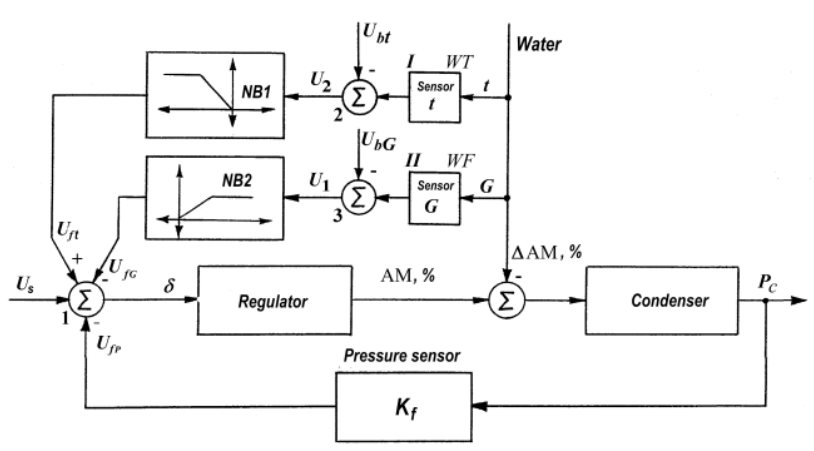

Fig. 6 - Structural scheme of the condensing pressure control with flow sensors BG and BT temperature of the cooling water

The resulting signal $\delta$ supplies to the regulator input, and its value is determined by the algebraic sum of the set signals and feedback connection:

$$
\delta=U_{s}-U_{f P}-U_{f G}+U_{f t}
$$

From this expression it is obviously that the regulation error $\delta$, and hence the condensing pressure set value $P_{c s}$ depends not only from the set voltage $U_{s}$ at the input of the regulator but it could be reduced during operation process.

As can be seen in this figure, it is very important that during the system configuration the regulation of voltage balancing $U_{b G}, U_{b t}$ and dependencies of the nonlinear blocks NB1 and NB2 to obtain such mode when feedback connections signals $U_{f G}$ and $U_{f t}$ equal zero during nominal water flow and temperature. If it is deviation from the nominal values of cooling water flow and (or) temperature that nonlinear blocks NB1 and NB2 will take effect.

Let the condensing pressure of the $P_{c}$ was constant, unchanged value for a set level $P_{c s}$. In the case of reduction water flow relative to the nominal value voltage $U_{s G}$ will remain equal to zero, because $U_{1}<0$ and a form of nonlinear dependence of the block NB1. As a result, the process of condensing pressure control will be similar to the processes in system which shown in Fig. 1, a, b. But with the increase in water flow, the voltage $U_{1}$ becomes greater than zero, and the signal $U_{s G}$ will begin to be deducted from set value $U_{s}$, thereby reducing the value $\delta$, and hence the static condensing pressure of the refrigerant (see Fig. 1, d). As described above, the regulation process of the condensing pressure will pass through the water temperature channel.

The plus sign at the adder input 1 means an increase of the resulting signal $\delta$, and hence the flow of cold water by increasing of its temperature.

Sections "limitations" of the nonlinear characteristics of the blocks NB1 and NB2 are inset for limitation of the minimum value of the condensing pressure with a significant lowering of temperature or increase of flow of the cooling water.
The physical implementation of the proposed system is obvious. The standard measuring devices with analog electric signals are used as temperature and water flow sensors. Typical blocks of the direct current supply are sources of balancing voltages. The nonlinear blocks with the comparing elements might be operational amplifiers with suitable nonlinear correction. For modern refrigeration systems are also accepted software implementation of the automation system, including nonlinear dependencies realized by programmable controllers.

The second way of condensing pressure regulation admits the disconnection of the feedback circuit by the condensing pressure $P_{c}$. With such switching-on, the regulator will respond only to deviations $P_{c}$ to the side more than $P_{c s}$, so it will respond on positive disturbances. If $P_{c}$ is less than $P_{c s}$, the regulator feedback circuit breaks. The proposed control scheme (Fig. 7) in comparison with the known (see Fig. 5, a, b) differs with the additional logical block and a switch $S$. The last could be in position:"1" - the feedback system is closed and "2" feedback system is open.

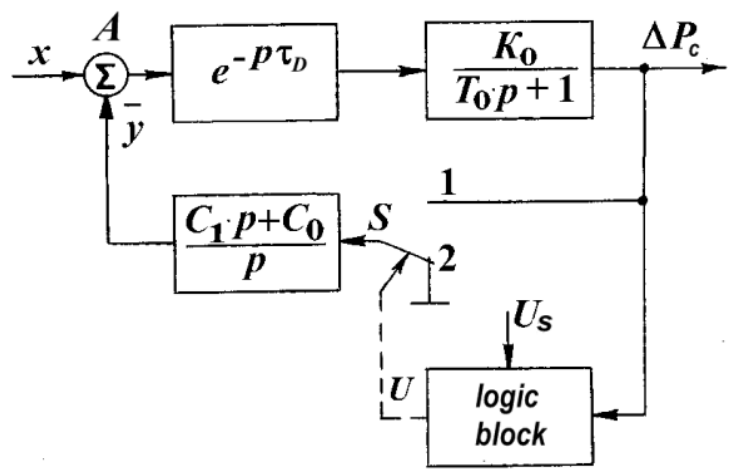

Fig. 7 - Structural scheme of condensing pressure control system with logical block

The position of the switch at any time moment depends on the output signal of the logic block $U$. The signal level is determined by the value $P_{c}$ and can take one of two values (a logical zero or logical one).

Function rule of logic block is following:

$$
\begin{aligned}
& U=1, \text { when } P_{c}>P_{c s}, \\
& U=0, \text { when } P_{c}<P_{c s} .
\end{aligned}
$$

Setpoint actuation $U_{s}$ of the logical block is regulated in the process of the system adjustment and changes the levels of switch actuation $S$.

The most efficient operation of the proposed system in such cases, when the refrigeration unit operates in significant deviations modes that significantly differ from the estimated modes. This position are illustrated by the dynamic processes graphs of the condensing pressure regulation (Fig. 8), constructed by using the Matlab environmental ( 1 - for system with conventional PIcontroller, 2 - for system with an additional built-in logic block). 

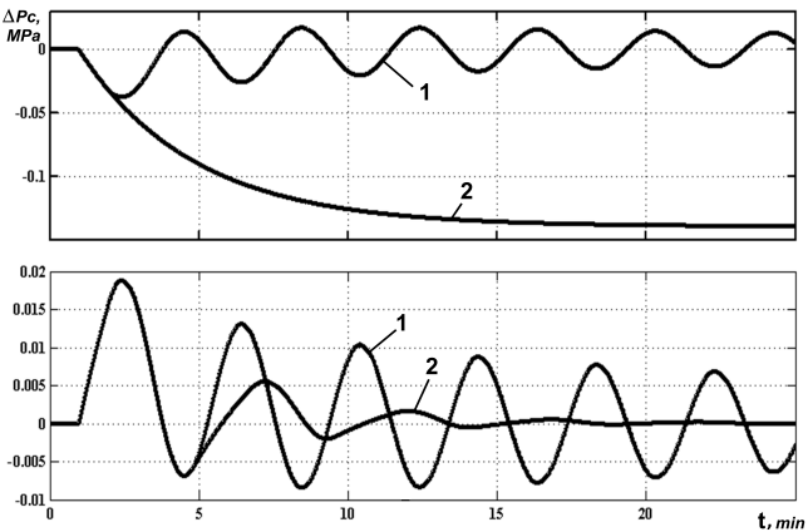

Fig. 8 - Condensing pressure stabilization processes in the shell-and-tube condenser $\left(\triangle P_{c}, M P a\right)$ :

a) if perturbation is positive, $b$ ) if perturbation is negative;

1 - system with conventional PI-controller, 2 -system with an optional built-in logic block

Trawler ship refrigeration unit shell-and-tube condenser was modeled as the aperiodic link with a delay link

$$
W_{O}(p)=\frac{K_{O}}{T_{O} \cdot p+1} \cdot e^{-p \tau_{D}}
$$

and regulator has implemented proportional-integral (PI) control law [11]

$$
W_{R}(p)=\frac{C_{1} \cdot p+C_{0}}{\partial}
$$

The system control parameters are taken directly from the passport regulator PIC-6800 ship refrigeration units: $C_{0}=110 \% \mathrm{AM} /(\mathrm{MPa} \cdot \min ), C_{1}=430 \% \mathrm{AM} / \mathrm{MPa}$.

The dynamic parameters of the condenser are defined by the calculation method and have the following meanings: $\tau_{D}=0.98 \mathrm{~min}, T_{O}=3.9 \mathrm{~min}, K_{O}=0.014 \mathrm{MPa}$ for $1 \%$ of the actuator motion (AM) that is the regulated valve with electric actuator, which is installed on the water supplying pipeline to the condenser.

The perturbations $X=5 \%$ AM was introduced in both systems and the amount of deviation $\Delta P_{\kappa}$ was registered, at the regulator constant setting and $P_{c s}=0$ (deviation mode from the condensing pressure absolute set value) in the researched model [11-13]. Curve 1 shows that the regulating process in case of a positive perturbation flow tight, it is characterized by high frequency and significant amplitude of the condensing pressure fluctuations.

The time of the transition process and the degree of condensing pressure fluctuation is greatly reduced during the transition to the proposed scheme (curve 2). The frequency of pressure fluctuations was also decreased. Such character of the process explains by the ratio of the dynamic parameters of the condenser, regulator with logical block and their interaction which leads to the following.
During the transition process, when $P_{c}<P_{c i}$ (regulator is turned off), the value of $\Delta P_{c}$ has a positive value because of a delay in the system. As a result, the pressure $P_{c}$ will grow and after some time it exceeds the set value (for the deviation mode it has zero meaning) and this will act to the regulator re-operation. This process will be repeated until then condensing pressure will not fix at a given value of $P_{c s}$ which is provided by the integral part of regulator.

It is obvious that if a large negative perturbation will go at the input of the proposed system, for example $X=-10 \% \mathrm{AM}$, then the regulator will switch off the feedback circuit and the condenser pressure in a static mode will differ from the setpoint by the value

$$
P_{c}=K_{O} \cdot X=0.014 \cdot(-10)=-0,14 \mathrm{MPa} \text {. }
$$

In this case, the condensing pressure is established at lower level and therefore the load on the compressor was decreased. For comparison, in the conventional system the stabilization process went to a fixed, predetermined pressure that is energetically unfavorable in such situation.

Matlab model of the system according to the shown scheme in Fig. 7 are fairly obvious, and its implementation on the analog element base is known [12]. Software implementation of control algorithm on the microcontroller of the refrigeration unit is also very simple and follows directly from the view in Fig. 7 schemes.

Thus, the developed block diagrams and simple algorithms of the condensing pressure regulation use the principles of partial invariance to main disturbances with elements of nonlinear correction and variable structure.

\section{Conclusions}

Hardware or software using of the proposed control algorithms improve the quality of dynamic processes. It was proved in the described examples with simulation of processes in shell-and-tube condenser KTP300 of the ship refrigeration units and control systems for air condenser. This is especially obvious when it is the significant and frequent changes of thermal loads on ship refrigeration unit.

The resulting value of the getting energy effect is obvious, but requires further economic calculations for a specific refrigeration unit.

\section{Список літератури}

1. Желіба, Ю. О. Енергозбереження при виробництві та споживанні холоду / Ю. О. Желіба // Холод. Монтаж + Технологія. - 2004. - № 2. - С. 39-43.

2. Head Pressure Controllers [Електронний pecypc] / EDC International Ltd. - Режим доступу: IWWW/ URL: http://www.edcpumps.com/upload/Operating-manual-HeadPressure-Controller.pdf - 27.08.2009 p.

3. Пат. US20150042260 A1 США, H02P 21/0035 (2013.01). Electrical solution for saving power and expenses / Harry N. Sturm (США); заявник и патентовласник Harry N. Sturm. - № US 14/382,655; заявл. 04.03.2013; опубл. 12.02.2015. 
4. Emadi, A. Advanced Electric Drive Vehicle / A. Emadi. Boca Raton, FL: CRC Press, 2015. - 586 p.

5. Онищенко, О. А. Современный электропривод для систем холодильной техники / В. И. Живица, О. А. Онищенко, И. Н. Радимов, и др. // Холодильная техника и технология. - 1999. - № 64. - С. 112-116.

6. Hughes, A. Electric Motors and Drives: Fundamentals, Types and Applications / A. Hughes, B. Drury. - [4 ed.] Oxford: Newnes, 2013. - 440 p.

7. Онищенко, О. А. Повышение энергетического фактора вентильно-индукторных электроприводов О. Я. Карпович, О. А. Онищенко // Вестник НТУ «ХПИ». - 2005. - № 45. - С. 400-404.

8. Букарос, А. Ю. Коректор коефіцієнта потужності для частотно-регульованого електроприводу / А. Ю. Букарос // Східно-європейський журнал передових технологій. - 2012. - Т. 57 № 3/8. - С. 4-8.

9. Dossat, R. J. Principles of Refrigeration / R. J. Dossat, T. J. Horan. - Noida: Pearson, 2010. - 454 p.

10. Maurer, T. Kältetechnik für Ingenieure / T. Maurer. GmbH: VDE Verlag, 2016. - 575 p.

11. Li, S. X. Dynamic Modeling of Steam Condenser and Design of PI Controller Based on Grey Wolf Optimizer / S. X. Li, J.S. Wang // Mathematical Problems in Engineering. - 2015. - № 2015. - P. 1-9. doi: $10.1155 / 2015 / 120975$.

12. Онищенко, О. А. Электропривод систем температуры конденсации холодильных установок / О. А. Онищенко // Електромашинобудування та електрообладнання. - 2006. - № 66. - С. 190-192.

13. Онищенко, О. А. Підвищення енергетичної ефективності суднових холодильних установок / А. А. Лепський, О. А. Онищенко // Науково-технічна конференція молодих дослідників "Суднові енергетичні установки: експлуатація та ремонт", Одеса. - 2014. C. $95-102$.

\section{Bibliography (transliterated)}

1 Zheliba, Ju. O. Energhozberezhennja pry vyrobnyctvi ta spozhyvanni kholodu [The conservation of energy during cold production and consumption]. Kholod. Montazh + Tekhnologhija [Refrigeration. Installation + Technology], 2004, 2, 39 - 43.

2 Head Pressure Controllers. EDC International Ltd, 2009, http://www.edcpumps.com/upload/Operating-manual-HeadPressure-Controller.pdf. Accessed 27 Aug. 2009.
3 Harry, N. S. Electrical solution for saving power and expenses. Patent US, no. US20150042260 A1, 2015.

4 Emadi, A. Advanced Electric Drive Vehicle. Boca Raton, FL: CRC Press, 2015.

5 Zhivica, V. I., Onishhenko, O. A., Radimov, I. N., et al. Sovremennyj jelektroprivod dlja sistem holodil'noj tehniki [Modern electric drive for refrigeration units systems]. Holodil'naja tehnika $i$ tehnologija [Refrigeration engineering and technology], 1999, 64, 112-116.

6 Hughes, A., Drury, B. Electric Motors and Drives: Fundamentals, Types and Applications. 4 ed. Oxford: Newnes, 2013.

7 Karpovich, O. Ja., Onishhenko, O. A. Povyshenie jenergeticheskogo faktora ventil'no-induktornyh jelektroprivodov [The power factor rising of the switchedrelutrance electric drives]. Visnyk NTU "KhPI" [Messenger of SI "KhPI"], 2005, 45, 400-404.

8 Bukaros, A. Ju. Korektor koeficijenta potuzhnosti dlja chastotno-reghuljovanogho elektropryvodu [The power factor corrector of the frequency-controlled electric drive]. Skhidno-jevropejsjkyj zhurnal peredovykh tekhnologhij [Eastern-European Journal of Enterprise Technologies], 2012, 3/8(57), 4-8.

9 Dossat, R. J., Horan T. J. Principles of Refrigeration. Noida: Pearson, 2010.

10 Maurer, T. Kältetechnik für Ingenieure. GmbH: VDE Verlag, 2016.

11 Li, S. X., Wang, J. S. Dynamic Modeling of Steam Condenser and Design of PI Controller Based on Grey Wolf Optimizer. Mathematical Problems in Engineering, 2015, 2015, 1-9, doi:10.1155/2015/120975.

12 Onishhenko, O. A. Jelektroprivod sistem temperatury kondensacii holodil'nyh ustanovok [Electric drive of the refrigeration units temperature condensing systems]. Elektromashinobuduvannja ta elektroobladnannja [Electrical machinery and electrical equipment], 2006, 66, 190-192.

13 Onishhenko, O. A., Leps'kij, A. A. Pidvishhennja energetichnoï efektivnosti sudnovih holodil'nih ustanovok [The energy efficiency raising of ship refrigeration units]. Naukovo-tekhnichna konferencija molodykh doslidnykiv "Sudnovi energhetychni ustanovky: ekspluatacija ta remont" [Scientific and technical conference of young researchers "Ship Power Plants: Maintenance and repair"], Odesa, 2014, 95-102.

\section{Сведения об авторах (About authors)}

Букарос Валерія Миколаївна - аспірант, Національний університет «Одеська морська академія», асистент кафедри технічної експлуатації флоту; м. Одеса, Україна; e-mail: eralife84@gmail.com.

Valeriya Mykolayevna Bukaros - Postgraduate Student, Assistant, Department of Fleet Operation and Maintenance, National University "Odessa Maritime Academy", Odesa, Ukraine; e-mail: eralife84@ gmail.com.

Онищенко Олег Анатолійович - доктор технічних наук, професор, Національний університет «Одеська морська академія», професор кафедри технічної експлуатації флоту, м. Одеса, Україна; e-mail: oleganaton@ gmail.com.

Oleg Anatolyevych Onishchenko - Doctor of Technical Sciences, Professor, National University "Odessa Maritime Academy", Department of Fleet Operation and Maintenance, Odesa, Ukraine; e-mail: oleganaton@ gmail.com.

Налева Галина Василівна - кандидат технічних наук, доцент, Національний університет «Одеська морська академія», доцент кафедри вищої математики, м. Одеса, Україна; e-mail: naleva_gv@mail.ru.

Galyna Vasylivna Naleva - Candidate of Technical Sciences (Ph. D.), Docent, Department of Higher Mathematics, National University "Odessa Maritime Academy", Odesa, Ukraine; e-mail: naleva_gv@mail.ru.

Букарос Андрій Юрійович - кандидат технічних наук, доцент, Одеська національна академія харчових технологій, доцент кафедры электротехника и робототехника, г. Одесса, Украина; e-mail: andrey.bucaros@gmail.com.

Andrii Yuriyovych Bukaros - Candidate of Technical Sciences (Ph. D.), Docent, Department of Electromechanics and Mechatronics, Docent, Odessa National Academy of Food Technologies, Odesa, Ukraine; e-mail: andrey.bucaros@ gmail.com. 
Please cite this article as:

Bukaros, V., Onishchenko, O., Naleva, G., Bukaros, A. Automation of the control processes of the refrigeration units condensers. Bulletin of NTU "KhPI". Series: New solutions in modern technologies. - Kharkiv: NTU "KhPI", 2017, 23 (1245), 7683, doi:10.20998/2413-4295.2017.23.12.

Будь ласка, посилайтесь на июю статтю наступним чином:

Букарос, В. М. Автоматизація процесів керування конденсаторами холодильних установок / В. М. Букарос, О. А. Онищенко, Г. В. Налева, А. Ю. Букарос// Вісник НТУ «ХПІ», Серія: Нові рішення в сучасних технологіях. - Харків: НТУ «ХПІ». - 2017. - № 23 (1245). - С. 76-83. - doi:10.20998/2413-4295.2017.23.12.

Пожалуйста, ссылайтесь на эту статью следующим образом:

Букарос, В. М. Автоматизация процессов управления конденсаторами холодильных установок / В. Н. Букарос, О. А. Онищенко, Г. В. Налева, А. Ю. Букарос // Вестник НТУ «ХПИ», Серия: Новые решения в современных технологиях. - Харьков: НТУ «ХПИ». - 2017. - № 23 (1245). - С. 76-83. - doi:10.20998/2413-4295.2017.23.12.

АННОтАЦИЯ Методами имитационного моделирования проведён сравнительный анализ схемотехнических решений регуляторов температуры конденсачии. Обоснована иелесообразность реализации регулятора температуры конденсачии на базе трёхфазного преобразователя частоты со звеном постоянного тока. Проведено исследование двух систем управления охлаждением водяных конденсаторов холодильных установок. Доказано, что использование предложенных алгоритмов управления позволит повысить энергетическую эффективность холодильных установок и качество динамических процессов управления при значительных колебаниях тепловых нагрузок.

Ключевые слова: холодильная установка; конденсатор; давление конденсации; регулятор температуры конденсации; система управления. 